\title{
Identification of Malignant Plasma Cell Precursors in the Bone Marrow of Multiple Myeloma
}

F. Caligaris-Cappio, L. Bergui, L. Tesio, G. Pizzolo, F. Malavasi, M. Chilosi, D. Campana, B. van Camp, and G. Janossy Cattedra di Clinica Medica A, Istituto di Medicina Interna, Universita di Torino, Italy; Cattedra di Ematologia, Universita di Verona, Italy; Istituto di Genetica Medica, Universita di Torino, Italy; Istituto di Anatomia Patologica, Universita di Verona, Italy;

Department of Haematology, Free University, Brussels, Belgium; Department of Immunology, Royal Free Hospital School of Medicine, London NW3, United Kingdom

\begin{abstract}
Precursors of plasma cells were studied in the bone marrow of 28 patients with multiple myeloma, plasma cell leukemia, and benign monoclonal gammopathy. Pre-B and B cell populations were analyzed with anti-B monoclonal antibodies corresponding to the clusters standardized at the Leucocyte Typing Workshops in Paris and Boston (CD9, CD10, CD19-22, CD24). In advanced forms of plasma cell malignancies, such as cases of multiple myeloma in stages II and III and of plasma cell leukemia, some cells of lymphoid morphology expressed common acute lymphoblastic leukemia antigen (CALLA, CD10) and HLA-DR, but contained no detectable terminal deoxynucleotidyl transferase enzyme. These CALLA ${ }^{+}$cells were absent in benign monoclonal gammopathies. In multiple myeloma, the $\mathrm{CALLA}^{+}$cells were negative for surface and cytoplasmic immunoglobulins (Ig), and, unlike CALLA ${ }^{+}$, terminal deoxynucleotidyl transferase $\left(\mathrm{TdT}^{+}\right)$ pre- $B$ cells in the normal bone marrow also failed to react with antibodies to B cell-associated antigens such as CD9, CD19, $\mathrm{CD22}$, and $\mathrm{CD24}$. The $\mathrm{CALLA}{ }^{+}, \mathrm{Ig}^{-}$cells could be regarded as preplasmacytic since, after having been separated and stimulated with the phorbol ester 12-0-tetradecanoyl-phorbol-13 acetate in vitro, they transformed into plasma cells and synthesized the same heavy and light chains as myeloma cells.
\end{abstract}

\section{Introduction}

Plasma cells are at the final stage of antigen-driven B lymphocyte activation, division, and differentiation, and they lose the capacity to proliferate (1). Malignant plasma cells in multiple myeloma $(\mathrm{MM})^{1}$ have a low growth fraction with long cell cycle,

Address reprint requests to Dr. Caligaris-Cappio, Cattedra di Clinica Medica A, Via Genova 3, 10126 Torino, Italy.

Received for publication 20 February 1985.

1. Abbreviations used in this paper: APAAP, alkaline phosphatase antialkaline phosphatase; BM, bone marrow; BMG, benign monoclonal gammopathy; C, chicken; CALLA, common acute lymphoblastic leukemia antigen; CD, cluster differentiation; cylg, cytoplasmic Ig; FACS, fluorescence-activated cell sorter; FCS, fetal calf serum; FH, Ficoll-Hypaque; FITC, fluorescein isothiocyanate; G, goat; GC, germinal center; IF, immunofluorescence; IP, isolated plasmacytoma; M, mouse; MAB(s), monoclonal antibodies; MM, multiple myeloma; PBL, peripheral blood lymphocyte; PCL, plasma cell leukemia; PWM, pokeweed mitogen; $R$, rabbit; S, swine; slg, surface Ig; TdT, terminal deoxynucleotidyl transferase; TPA, 12-0-tetradecanoyl-phorbol-13 acetate; TRITC, tetraethylrhodamine isothiocyanate.

J. Clin. Invest.

(C) The American Society for Clinical Investigation, Inc.

0021-9738/85/09/1243/09 \$1.00

Volume 76, September 1985, 1243-1251 and mitotic figures are rare (2). Kinetic studies in vivo also indicate that the proliferating pool in $\mathrm{MM}$ is not self-maintaining, but represents a transit compartment (3). These observations suggest that precursor (clonogenic) cells may exist that "feed" the plasma cell compartment. Another feature of MM is its dissemination in different bones. But few plasma cells are seen in the circulation, and only at the terminal phase of the disease. The disease may therefore spread through the circulating blood by precursor cells, which show lymphoid rather than plasma cell morphology. Transplantation experiments in murine myeloma have shown that neoplastic cells progressively differentiate from small, nonsecretory elements into large secretory plasmacytoid cells (4), and that the clonogenic cells that propagate the disease are present in the blood but lack myeloma cell morphology (5).

In man, malignant plasma cell precursors have been studied with a clonogenic assay (6), but the membrane marker features of clonally expanding cells have not been established. The single specific marker for the MM malignant clones is their unique Ig idiotype. However, it is still unresolved whether or not pecursor cells in MM show idiotypic Ig determinants on their membrane and/or within their cytoplasm. In this paper, we have therefore investigated pre-B and B cell types in bone marrow (BM) samples infiltrated with MM. A range of $B$ cell and plasma cell associated monoclonal antibodies (MABs) corresponding to those standardized at the Leucocyte Typing Workshops in Paris (7) and Boston (8) were applied. In addition, we have attempted to induce plasma cell differentiation in the various populations with phorbol ester 12-0-tetradecanoyl-phorbol-13 acetate (TPA).

In the present paper, we provide evidence that in advanced forms of plasma cell malignancies such as MM, stages II and III (9), and in plasma cell leukemia (PCL), cells of lymphoid morphology are present that express common acute lymphoblastic leukemia antigen (CALLA, CD10) and HLA-DR, but do not contain terminal deoxynucleotidyl transferase ( $\left.\mathrm{TdT}^{-}\right)$and are negative for both surface Ig (sIg) and cytoplasmic Ig (cyIg) as well as for B cell antigens CD19-22. When these CALLA ${ }^{+}, \mathrm{Ig}^{-}$ cells are separated with a fluorescence-activated cell sorter (FACS), and stimulated with TPA in vitro, the induced cells transform into plasma cells that synthesize the heavy and light chains displayed by the patients' myeloma cells.

Patients. Patients were defined according to the Chronic Leukemia-Myeloma task force of the National Cancer Institute, Bethesda, MD (10). 23 patients with MM were studied, 8 males and 15 females (age 43-76 yr); 17 had monoclonal Ig of IgG type and four had IgA. One patient produced IgD and another had light chain only ( $\lambda$-type). The light chains were $k$ in 12 cases and $\lambda$ in the remaining 11 . Nine patients were in stage $I$, eight in stage II, and six in stage III (9). Two patients (one male, 65yr-old, and one female, 59-yr-old) had aggressive PCL, and presented with hepatosplenomegaly and anemia. Both had a rapid, fatal course. One patient, a 35-yr-old female, had isolated plas- 
macytoma (IP) with a single osteolytic lesion localized to the sternum. At this site the plasma cell infiltrate had $\mathrm{IgG} / \mathrm{k}^{+}$plasma cells, and at other sites the BM contained normal, low proportions (0.5-2\%) of polyclonal plasma cells. A monoclonal serum component $(1 \mathrm{~g} / \mathrm{dl})$ was detected in the serum. Three patients (one male, two females, aged 45,50 , and $52 \mathrm{yr}$ ) had benign monoclonal gammopathy (BMG). The levels of monoclonal Ig were $<3 \mathrm{~g} / \mathrm{dl}$ with $<10 \%$ plasma cells in BM. Bone lesions, anemia, renal insufficiency, and other evidence of disease progression have not been observed in the 5-yr-period preceding our study.

\section{Methods}

Cells and tissues studied. The samples examined were: (a) BM tissue from 23 patients with MM and from three patients with BMG; $(b)$ peripheral blood lymphocytes (PBL) from 14 patients with $\mathrm{MM}$, two patients with PCL, and two patients with BMG; $(c)$ a specimen of the neoplastic tissue obtained with biopsy from the patient with a plasmocytoma of the sternum. Plasma cells from normal healthy individuals were also studied. These were from: ( $a$ ) the BM samples of four patients with no identifiable haematological disorders, as indicated by the normal histology seen on trephine biopsies; $(b)$ five samples of tonsil tissue removed from children undergoing tonsillectomy after antibiotic treatment; (c) cells harvested from pokeweed mitogen (PWM)-stimulated peripheral blood. These cells were cultured for $8 \mathrm{~d}$ in flat-bottomed microtiter plates (Nunc, Kamstrup, Denmark). The stimulating dose of PWM (Gibco Laboratories, Grand Island, NY) was $4 \mathrm{ng} / \mathrm{ml} \mathrm{(11).}$

B blast cells deriving from the germinal center (GC) were separated from tonsils (three samples) with a FACS 420 (Becton-Dickinson \& Co., Mountain View, CA). The tonsil suspensions were reacted with the MAB
RFA-2, which detects an antigen expressed on both $T$ cells in the paracortical region and B cells in the mantle zone, but not on GC B blasts (12). The cells unreactive with RFA-2 were sorted. Two acute lymphoblastic leukemia cell lines were also used in the present study: KM3 and Nalm-6 (13). The cell lines were grown in RPMI 1640 supplemented with $10 \%$ fetal calf serum (FCS) at $37^{\circ} \mathrm{C}$ in air containing $5 \% \mathrm{CO}_{2}$.

Preparation of cells. Mononuclear cells were separated from blood and BM on Ficoll-Hypaque (FH). The cells in the interphase were washed twice with phosphate-buffered saline (PBS) and resuspended in RPMI medium plus $10 \%$ FCS. Tonsils and the IP surgical samples were teased with blunt forceps, and suspensions were separated on FH and resuspended in RPMI containing 10\% FCS. After incubation in vitro PBL, GC B blasts, KM3, and Nalm-6 cells were resuspended in RPMI plus $10 \%$ FCS. Multiple cytocentrifuge smears $\left(2.5 \times 10^{5}\right.$ cells/slide $)$ were obtained and stained with antibody combinations (see below).

Antibodies. Rabbit (R) and goat (G) antisera to human Ig isotypes $(\gamma, \alpha, \mu, \delta, \kappa, \lambda)$ conjugated with fluorochrome tetraethylrhodamine isothiocyanate (TRITC) were purchased from Dakopatts, Glostrup, Denmark (Cat. R-151, R-153, R-152, R-148, R-154, and R-155) and from Cappell Laboratories, Cochranville, PA (Cat. 2201-0081, 2201-0021, 2201-0201, 2001-0051, 2201-0241, and 2201-0281). These antibodies were used in direct immunofluorescence (IF).

Chicken (C) anti-HLA-DR, a gift from Dr. A. Sullivan, McGill University, Montreal, Canada, was employed to detect HLA-DR Ia-like antigens; R-anti-TdT (Supertech Inc., Bethesda, MD, Cat. 004) was used to detect the nuclear enzyme TdT. Both C-anti-HLA-DR and R-antiTdT were used in indirect IF assays with G-anti-C-TRITC and swine (S) anti-R-Ig-TRITC second layers, respectively.

The MABs to B cell-associated and -specific antigens (14-20) included J5, VIL-AI and RFAL1 (CD10), BA2 (CD9), BA1 (CD24), B4 (CD19), B1 (CD20), RFB6 (CD21), and RFB4 (CD22; Table I). Three further

Table I. B Cell-restricted and B Cell-associated MABs Used in This Study

\begin{tabular}{|c|c|c|c|c|c|c|c|}
\hline Name & Class & Mol wt & $\mathrm{CD}^{*}$ & Specificity & Cross-reactivity & Source & Reference \\
\hline BA-1 & IgM & 30 & 24 & $\mathrm{~B}$ cells & Granulocytes & $\begin{array}{l}\text { Hybritech, Inc. (San } \\
\text { Diego, CA) }\end{array}$ & 18 \\
\hline BA-2 & IgG3 & 24 & 9 & $\begin{array}{l}\text { Early B and pre-B } \\
\text { cells }\end{array}$ & Myeloblasts & Hybritech, Inc. & 20 \\
\hline B4 & IgG1 & 40,80 & 19 & $\begin{array}{l}\text { All B, from pre-B } \\
\text { cells onward }\end{array}$ & None & $\begin{array}{l}\text { Coulter Electronics } \\
\text { Inc. }\end{array}$ & 16 \\
\hline B1 & IgG2 & 32 & 20 & $\begin{array}{l}\text { All B, from pre-B } \\
\text { cells onward }\end{array}$ & None & $\begin{array}{l}\text { Coulter Electronics } \\
\text { Inc. }\end{array}$ & 17 \\
\hline RFB4 & IgG1 & 140 & 22 & $\begin{array}{l}\text { Mature } \text { sIgM }^{+}, \text {sIgD }^{+} \\
\quad \text { B cells }\end{array}$ & None & $\begin{array}{l}\text { Royal Free Hospital } \\
\text { (London, En- } \\
\text { gland) }\end{array}$ & 19 \\
\hline RFB6 & IgG1 & 180 & 21 & $\begin{array}{l}\text { Mature } \operatorname{sIgM}^{+}, \text {sIgD }^{+} \\
\text {B cells }\end{array}$ & $\begin{array}{l}\text { Follicular dendritic } \\
\text { cells. Some T- } \\
\text { ALL lines }\end{array}$ & Royal Free Hospital & 19 \\
\hline J5 & IgG2 & 100 & 10 & Early B, few pre-B & Granulocytes & $\begin{array}{l}\text { Coulter Electronics } \\
\text { Inc. }\end{array}$ & 14 \\
\hline VIL-A1 & IgM & 100 & 10 & Early $B$, few pre-B & Granulocytes & $\begin{array}{l}\text { Dr. W. Knapp } \\
\text { (Wien) }\end{array}$ & 15 \\
\hline RFAL1 $\ddagger$ & IgG1 & 100 & 10 & Early B, few pre-B & Granulocytes & Royal Free Hospital & 19 \\
\hline RFA2 & IgG1 & & & $\begin{array}{l}\text { Mature } \text { sIgM }^{+}, \text {sIgD }^{+} \\
\text {B cells, } T \text { cells }\end{array}$ & & Royal Free Hospital & 12 \\
\hline
\end{tabular}

* CD, cluster differentiation according to the Boston Workshop. $¥$ Competition experiments have shown that these three anti-CALLA reagents bind to the same molecular structure. Mol wt, molecular weight; e.g., $30=30,000$; ALL, acute lymphoblastic leukemia. 
reagents were: A10, detecting T10 antigen, expressed by some activated lymphohemopoietic cells and large granular lymphocytes (21); Leu-4 (Becton-Dickinson \& Co.), identifying T cells carrying CD3 (p19, 29) T cell-specific antigen, and $\mathrm{HAN}-\mathrm{PC}_{1}$, detecting a plasma cell-associated antigen (22). Chronic lymphocytic leukemia, hairy cell leukemia, and non-Hodgkin's lymphomas are HAN-PC - , while normal and malignant plasma cells are HAN-PC ${ }_{1}^{+}(22)$. These MABs were investigated in indirect IF assays with second layers G-anti-mouse (M)-IgG and R-anti-M-IgM conjugated with fluorescein isothiocyanate (FITC; both from BectonDickinson \& Co., Cat. 9031 and 1143). The alkaline phosphatase antialkaline phosphatase (APAAP) technique was also standardized (23), using unlabeled G-anti-M-Ig and an MAB anti-alkaline phosphatase (AP), a gift from Dr. D. Y. Mason, Oxford, England. Finally, in selected experiments, A10 and B1 were conjugated with biotin (B1-Biotin, Coulter Electronics Inc., Hialeah, FL, Cat. 6602470), and their reactivity was revealed by avidin-phycoerythrin (Becton-Dickinson \& Co., Cat. 9013).

Staining of cells. MABs were either used as culture supernatants in $1: 5$ final dilution or as purified $\mathrm{Ig}(2.5-10 \mu \mathrm{g} / \mathrm{ml}$, final dilution). Heterologous antisera were used at 1:50 final dilution. Cytospins were air dried, and fixed with cold acetone (for Ig and MAB-defined antigens) or with cold methanol (for TdT). MAB reactivity was defined by staining cells with two-color IF using the MAB plus G-anti-M-IgG-FITC or R-antiM-IgM-FITC together with R-or G-anti-human Ig isotype-TRITC. The morphology of reacting cells was studied with the APAAP technique (22). The TdT staining was performed as previously described (24).

Cell cultures. CALLA ${ }^{+}$cells were purified from five patients with MM (three samples of BM and two samples of PBL). J-5 and RFAL1 MABs, detecting identical epitopes on the p100 CALLA (CD10), were used for labeling and sorting on FACS 420. The CALLA ${ }^{+}$cells were suspended in RPMI 1640 medium plus $10 \%$ FCS at $1 \times 10^{6}$ cells $/ \mathrm{ml}$ and incubated for $72 \mathrm{~h}$ in $25-\mathrm{cm}^{2}$ tissue culture flasks (Nunc) at $37^{\circ} \mathrm{C}$ in air containing $5 \% \mathrm{CO}_{2}$. Duplicate cultures were set up as controls, and parallel samples were stimulated with TPA (first dissolved in acetone, $1.6 \times 10^{-3} \mathrm{M}$, and then in absolute alcohol, $1.6 \times 10^{-5} \mathrm{M}$ ). The final TPA concentration in the cultures was $1.6 \times 10^{-8} \mathrm{M}$, which, in preliminary experiments (25), was found to be optimal for inducing phenotypic changes in B cell malignancies without decrease in viability. Control and TPA-induced cells were harvested after $72 \mathrm{~h}$ and assessed for viability by trypan blue. The cell morphology and membrane markers were analyzed on cytocentrifuge smears (see above). Additional controls included a range of CALLA ${ }^{+}$cells, with both normal (GC B blasts) and malignant (Nalm 6 and KM3 cell lines) cultured under the same conditions.

\section{Results}

Cluster differentiation (CD) antigens in normal and malignant plasma cell samples. B-lineage antigens were studied on normal plasma cells obtained from different sources, and B4 (CD19), B1 (CD20), RFB6 (CD21), RFB4 (CD22), BA2 (CD9), and BA1 (CD24) were found to be absent irrespective of the samples' origin (BM, tonsil, or PWM-stimulated PBL). CALLA (CD10) was, nevertheless, weakly expressed on the surface of a few plasma cells in tonsil $(5 \pm 3 \%)$ and on occasional plasma cells in the BM or in PWM-stimulated cultures. All three CD10 antiCALLA MABs used (J5, VIL-A1, and RFAL1) gave the same results.

B lineage CD9, CD10, CD19-22, and CD24 antigens were also absent on plasma cells in MM and BMG (Table II). The cells of the solitary lesion in IP expressed the RFB6 (CD21) antigen (>85\%; Table II). The circulating plasma cells in PCL were also negative with B4, B1, RFB4, and RFB6 (Table II). The small mononuclear cell subset $(0.5-2 \%$ of BM cells) in these BM samples that reacted with these antibodies were $>90 \%$ slgM $^{+}$ and expressed $k$ or $\lambda$ chains in a "polyclonal" fashion (residual normal B cells). BA2 (CD9) and BA1 (CD24) were also unreactive with malignant plasma cells $(<1 \%)$. In contrast, CALLA (CD10) was weakly expressed by a variable percentage of plasma cells in 10/23 MM patients (Fig. 1, $a-c$, and Table II). 9 of the 10 patients with CALLA ${ }^{+}$plasma cells were in stage II or III, and only one patient was in stage I. In the remaining cases, $<5 \%$ of plasma cells were CALLA ${ }^{+}$.

When the analysis was focussed on the cells with lymphoid morphology, it became apparent that in all samples with CALLA $^{+}$plasma cells a subset of cells with lymphoid morphology $(4.2 \pm 3.6 \%)$ expressed CALLA (Fig. 1, $a-c$, and Table III). In $6 / 10$ of these patients, a few circulating cells were also $\mathrm{CALLA}^{+}(5 \pm 3 \%)$. In the remaining cases, very low proportions of CALLA ${ }^{+}$cells were seen in the BM, and no CALLA ${ }^{+}$lymphocytes could be detected in blood. The presence of CALLA ${ }^{+}$ cells was unrelated to the age or sex of patients, and it was independent of the isotype of monoclonal Ig.

In two patients with PCL, many circulating lymphocytes were $\mathrm{CALLA}^{+}$( 35 and $21 \%$, respectively). In the first case, the CALLA $^{+}$cells also included a few $(12 \%)$ plasma cells. In contrast to the observations in MM and PCL, all cases of BMG and the patient with solitary plasmocytoma lacked CALLA ${ }^{+}$lymphocytes ( $<1 \%$; Table II).

Characterization of MM CALLA cells. The CALLA ${ }^{+}$cells were further characterized in three steps. First, it was observed that in $\mathrm{CALLA}^{+} \mathrm{MM}$ samples, the percentages of lymphocytes

Table II. Reactivity of CD-directed MABs with Plasma Cells in Different Plasma Cell Disorders

\begin{tabular}{|c|c|c|c|c|c|c|c|c|c|c|c|c|c|}
\hline \multirow[b]{2}{*}{ Diagnosis } & \multirow[b]{2}{*}{ Stage } & \multirow[b]{2}{*}{$\begin{array}{l}\text { No. of } \\
\text { cases }\end{array}$} & \multicolumn{4}{|c|}{ Isotype } & \multirow[b]{2}{*}{$\begin{array}{l}\text { BA-1 } \\
\text { (CD24)§ }\end{array}$} & \multirow[b]{2}{*}{$\begin{array}{l}\text { BA-2 } \\
\text { (CD9) }\end{array}$} & \multirow[b]{2}{*}{$\begin{array}{l}\text { B4 } \\
\text { (CD19) }\end{array}$} & \multirow[b]{2}{*}{$\begin{array}{l}\text { B9 } \\
\text { (CD20) }\end{array}$} & \multirow[b]{2}{*}{$\begin{array}{l}\text { RFB6 } \\
\text { (CD21) }\end{array}$} & \multirow[b]{2}{*}{$\begin{array}{l}\text { RFB4 } \\
\text { (CD22) }\end{array}$} & \multirow[b]{2}{*}{ CALLA } \\
\hline & & & G & A & $\kappa$ & $\lambda$ & & & & & & & \\
\hline MM & I & 9 & 7 & 2 & 6 & 3 & $0 / 9$ & $0 / 9$ & $0 / 9$ & $0 / 9$ & $0 / 9$ & $0 / 9$ & $1 / 9^{\| \prime}$ \\
\hline MM & II & 8 & 7 & & 3 & 5 & $0 / 8$ & $0 / 8$ & $0 / 8$ & $0 / 8$ & $0 / 8$ & $0 / 8$ & $4 / 8 \pi$ \\
\hline MM & III & $6 \ddagger$ & 3 & 2 & 3 & 3 & $0 / 6$ & $0 / 6$ & $0 / 6$ & $0 / 6$ & $0 / 6$ & $0 / 6$ & $5 / 6^{* *}$ \\
\hline $\mathrm{PCL}^{*}$ & & 2 & 2 & & 1 & 1 & $0 / 2$ & $0 / 2$ & $0 / 2$ & $0 / 2$ & $0 / 2$ & $0 / 2$ & $1 / 2 \ddagger \ddagger$ \\
\hline BMG & & 3 & 3 & & 2 & 1 & $0 / 3$ & $0 / 3$ & $0 / 3$ & $0 / 3$ & $0 / 3$ & $0 / 3$ & $0 / 3$ \\
\hline IP & & 1 & 1 & & 1 & & $0 / 1$ & $0 / 1$ & $0 / 1$ & $0 / 1$ & $1 / 1$ & $0 / 1$ & $0 / 1$ \\
\hline
\end{tabular}

* Peripheral blood plasma cells were studied. $¥$ In one case the paraprotein was IgD. § Number of cases positive per number of cases tested. The percentage of plasma cells reacting with BA-1, BA-2, B1, B4, RFB4, and RFB6 was always $<1 \%$. In one IP case, $>85 \%$ plasma cells were RFB6 ${ }^{+}$. "The percentage of CALLA ${ }^{+}$plasma cells was $9 \%$ in one case, $<1 \%$ in the others. I The percentage of CALLA ${ }^{+}$plasma cells was 15,27, and $10 \%$ in three cases, $5 \%$ in a fourth case, and $<1 \%$ in the others. ${ }^{* *}$ The percentage of CALLA ${ }^{+}$plasma cells was $18 \pm 4.9 \%$, and $<1 \%$ in the remaining case. $\ddagger 12 \%$ were CALLA $^{+}$in one case, $<1 \%$ in the other. 

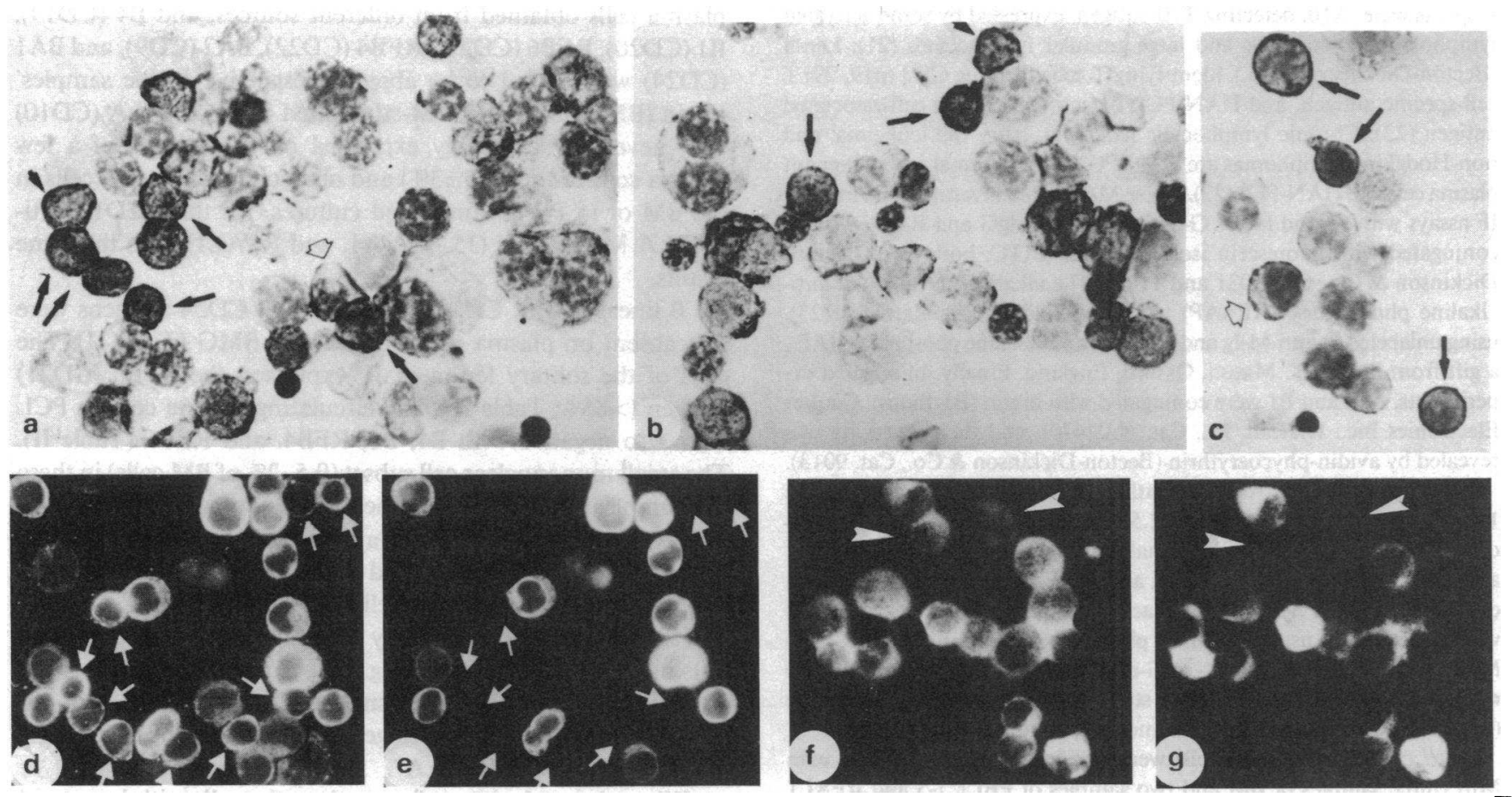

Figure 1. Expression of CALLA on BM cells from a patient with MM. $(a-c)$ APAAP technique showing strongly reacting lymphoid cells (full arrows) and weakly reacting plasma cells (empty arrows). Double immunofluorescence staining reveals that CALLA ${ }^{+}$lymphoid cells in $d$

are $\mathrm{Ig}^{-}(e)$. These cells are indicated by arrows. The combination of HAN-PC 1 antibody $(f)$ and staining for cylg $(g)$ reveals that some cells are HAN-PC ${ }_{1}^{+}$but cylg- (arrows).

expressing B4 (CD19), B1 (CD20), RFB6 (CD21), RFB4 (CD22), BA2 (CD9), and BA1 (CD24) were very low $(<2 \%)$. Double marker IF staining revealed that only the $B$ cell antigen-positive cells were $\operatorname{slgM}^{+}$, and these showed near normal $\kappa / \lambda$ ratios unrelated to the light chain made by MM cells. Thus, not only plasma cells, but also the CALLA ${ }^{+}$cells of lymphoid morphology lacked $B$ cell antigens. TdT staining was also consistently negative on CALLA ${ }^{+}$cells in all the samples tested. On the contrary, T10 antigen and $\mathrm{HAN}-\mathrm{PC}_{1}$ plasma cell antigen were expressed both

by monoclonal plasma cells and by smaller cells of lymphoid morphology, although in this latter population, T10 and HAN$\mathrm{PC}_{1}$ expression was weak.

In the second phase of investigation, double marker studies revealed that $\mathrm{CALLA}^{+}$cells were $\mathrm{HLA}_{-\mathrm{DR}^{+}}(>90 \%)$. The cells of lymphoid appearance lacked $\mathrm{sIg}$ and cylg (Fig. 1, $d$ and $e$ ) because the proportions of $\mathrm{CALLA}{ }^{+}, \mathrm{Ig}^{+}$cells in each case overlapped with that of CALLA ${ }^{+}$plasma cells. The CALLA ${ }^{+}, \mathrm{Ig}^{+}$ plasmacytoid cells expressed the same heavy and light chain

Table III. CALLA+ Cells in Plasma Cell Malignancies*

\begin{tabular}{|c|c|c|c|c|c|c|c|c|}
\hline \multirow[b]{2}{*}{ Case no. } & \multirow[b]{2}{*}{ Diagnosis } & \multirow[b]{2}{*}{ Stage } & \multicolumn{2}{|l|}{ BM } & \multirow[b]{2}{*}{ CALLA $^{+}$PC } & \multirow{2}{*}{$\begin{array}{l}\text { CALLA+ PC } \\
\text { within the PC } \\
\text { population }\end{array}$} & \multirow{2}{*}{$\begin{array}{l}\text { CALLA }{ }^{+} \\
\text {lymphocytes }\end{array}$} & \multirow{2}{*}{$\begin{array}{l}\text { CALLA }^{+} \\
\text {lymphocytes } \\
\text { within the } \\
\text { lymphocyte } \\
\text { population }\end{array}$} \\
\hline & & & Plasma cells & Lymphocytes & & & & \\
\hline & & & \% & $\%$ & $\%$ & $\%$ & \% & $\%$ \\
\hline 1 & $\mathbf{M M}$ & I & 45 & 15 & 4.3 & (9) & 4.5 & (28) \\
\hline 2 & $\mathbf{M M}$ & II & 40 & 8 & 2 & (5) & 0.4 & (5) \\
\hline 3 & $\mathbf{M M}$ & II & 30 & 13 & 3 & $(10)$ & 3 & (10) \\
\hline 4 & $\mathbf{M M}$ & II & 25 & 12 & 3.7 & (15) & 3.6 & (30) \\
\hline 5 & $\mathbf{M M}$ & II & 35 & 10 & 9.4 & (27) & 4.0 & $(40)$ \\
\hline 6 & $\mathbf{M M}$ & III & 30 & 15 & 7.5 & (25) & 7.0 & (45) \\
\hline 7 & $\mathbf{M M}$ & III & 36 & 12 & 4.3 & (12) & 4 & (30) \\
\hline 8 & $\mathbf{M M}$ & III & 40 & 10 & 8 & (20) & 6 & $(60)$ \\
\hline 9 & $\mathbf{M M}$ & III & 60 & 12 & 4.8 & (8) & 4 & (30) \\
\hline 10 & $\mathbf{M M}$ & III & 60 & 10 & 9 & (15) & 3.5 & (35) \\
\hline 11 & PCL & & 40 & 23 & 1 & (1) & 4.7 & (21) \\
\hline 12 & PCL & & 52 & 29 & 6.2 & (12) & 9.6 & (35) \\
\hline
\end{tabular}

PC, plasma cells. * 13 other cases with $\mathrm{MM}$ had $<0.1 \% \mathrm{CALLA}^{+}$cells. 
produced by the neoplastic plasma cells. Cells reacting with HAN-PC ${ }_{1}$ included both the CALLA ${ }^{+}$plasma cells $\left(\mathrm{cyIg}^{+}\right)$as well as the cylg${ }^{-}, \mathrm{sIg}^{-}$small lymphoid cells (Fig. $1, f$ and $g$ ).

Finally, CALLA ${ }^{+}$cells were separated by sorting from the BM of three MM patients (Nos. 1, 9, and 10), and from the blood of the two patients with PCL (Nos. 11 and 12; Table III): $85 \pm 3 \%$ of these CALLA ${ }^{+}$cells had a lymphoid appearance, and only a minority $(<15 \%)$ were plasmablasts or plasma cells (Fig. 2). Most lymphoid cells had an unremarkable morphology (Fig. $2 a$ ), but 5-10\% had an irregular nuclear morphology, with indentations (Fig. $2 b$, arrow) or signs of immaturity such as one or two nucleoli. CALLA ${ }^{+}$cells with clear signs of plasmacytic differentiation $(14 \pm 2 \%)$ were small in size and had a scanty cytoplasm (Fig. 2 c). The proportions of morphologically identifiable plasma cells were similar to the percentages of $\mathrm{Ig}^{+}$cells defined by immunofluorescence within the CALLA ${ }^{+}$population. The sorted CALLA ${ }^{+}$cells were also investigated with B1-Biotin (CD20) and T10-Biotin, and were found to be B1 negative $(<1 \%)$ and weakly $\mathrm{T} 10$ positive ( $>90 \%$ ).
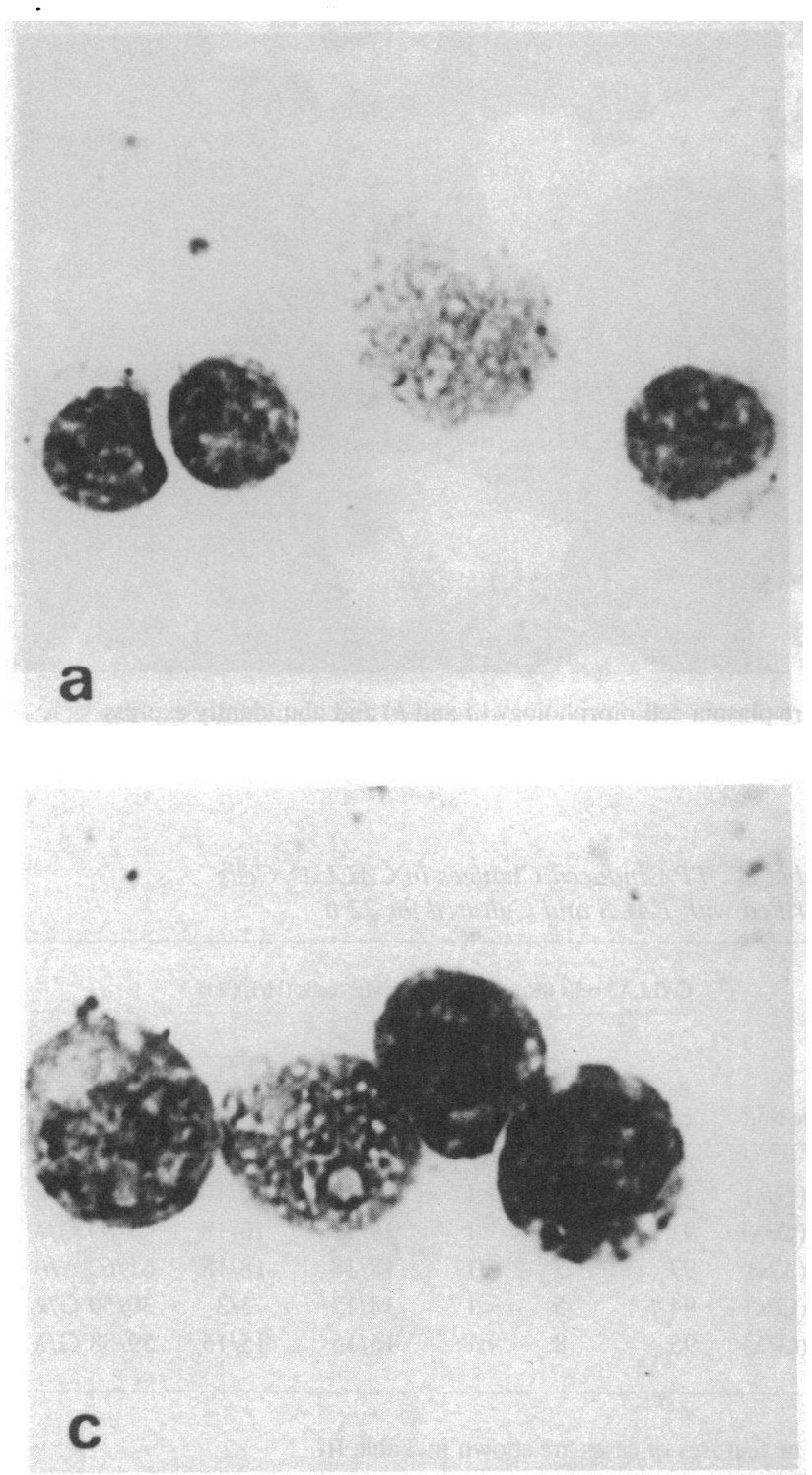

Figure 2. Morphology of CALLA ${ }^{+}$cells after cell sorting from a BM sample from a patient with MM. Small lymphoid cells, scanty ele-
CALLA ${ }^{+}$cells from $M M$ can be induced to acquire plasma cell features. CALLA ${ }^{+}$cells from five patients were separated and cultured in vitro with or without TPA. After $72 \mathrm{~h}$ in vitro, the viability was $>85 \%$, with $>80 \%$ cell recovery. The mitotic index was low (0-1\%) in both groups. Cells in control cultures without TPA did not show significant morphological changes, but most cells $(93 \pm 1.6 \%)$ had become CALLA $^{-}$. The percentage of cylg ${ }^{+}$cells remained low $(13 \pm 6 \%)$.

In contrast, the morphological analysis revealed changes in TPA-induced CALLA ${ }^{+}$cells (Fig. 3). Most elements had enlarged, and the cytoplasm became strongly basophilic (Fig. $3 a$ ); $20-45 \%$ of cells had acquired the appearance of plasma cells (Fig. $3 \mathrm{~b}$ ), sometimes with cytoplasmic vacuoli. These TPAtransformed cells had lost CALLA $(<1 \%)$, and no B-lineageassociated antigens could be detected on their membrane with antibodies CD19-22. On the other hand, a high percentage $(55 \pm 18 \%)$ of cells synthesized light and heavy chains (Fig. 3, $c$ and $d$ ). In each individual case, the Ig produced were of the same isotype as expressed by fresh, unstimulated MM and PCL
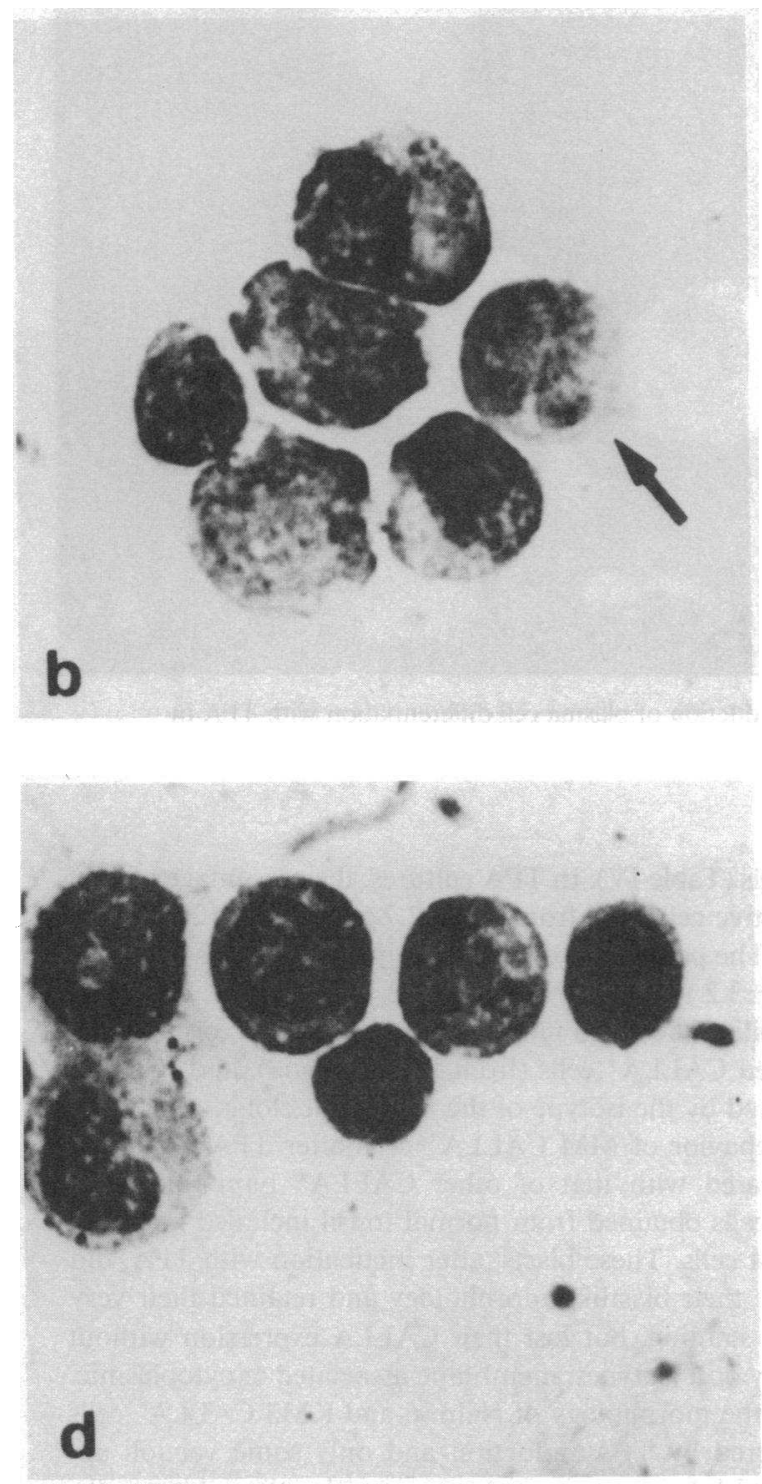

ments with nuclear irregularities ( $b$, arrow), immature cells with nucleolus ( $c$ and $d$ ), and small plasma cells are seen. 

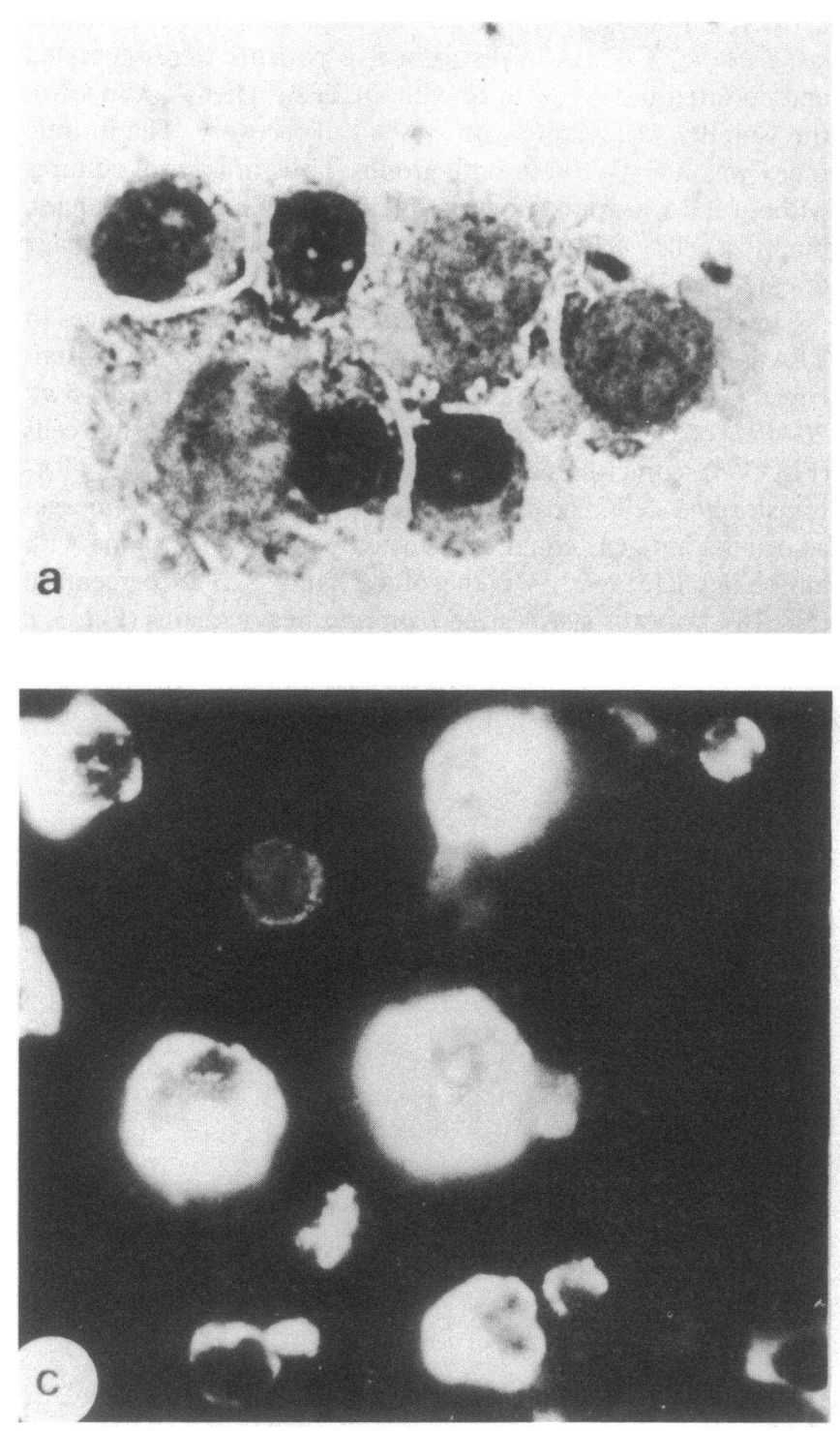

Figure 3. Induction of plasma cell differentiation with TPA in CALLA $^{+}$cells sorted from the BM infiltrates with MM. The cells ac-

plasma cells (Table IV). In TPA cultures, the percentage of light chain positive cells rose from $14.3 \pm 2.7$ to $53 \pm 6.9$ (12.6 \pm 6.0 in controls). The percentage of heavy chain positive cells increased from $14.6 \pm 3.2$ to $56 \pm 8.7$ ( $12.4 \pm 5.3$ in unstimulated controls). The capability of cells to make cylg was unrelated to the origin of separated CALLA ${ }^{+}$cells (from BM or blood), and was also uninfluenced by the isotype of the malignant clone.

The behavior of $\mathrm{MM} \mathrm{CALLA}^{+}$cells after TPA induction was compared with that of other $\mathrm{CALLA}^{+}$lymphoid cells. $\mathrm{CALLA}^{+}$cells obtained from normal tonsil included germinal center blast cells. These blasts, after incubation with TPA, did not change their blastlike morphology and retained their very weak cy- $\mu$ staining, but lost their CALLA expression without acquiring $\gamma$ or $\alpha$ isotypes, membrane associated or cytoplasmic. Similarly, the morphology of Nalm-6 and KM3 CALLA ${ }^{+}$cells was unaltered by TPA induction and only some vacuoli appeared. CALLA expression was retained by these blast cells. Nalm- 6 cells remained $c y-\mu^{+}$(as was observed at the initiation of cultures), while $\mathrm{KM} 3$ remained $\mathrm{Ig}^{-}$.
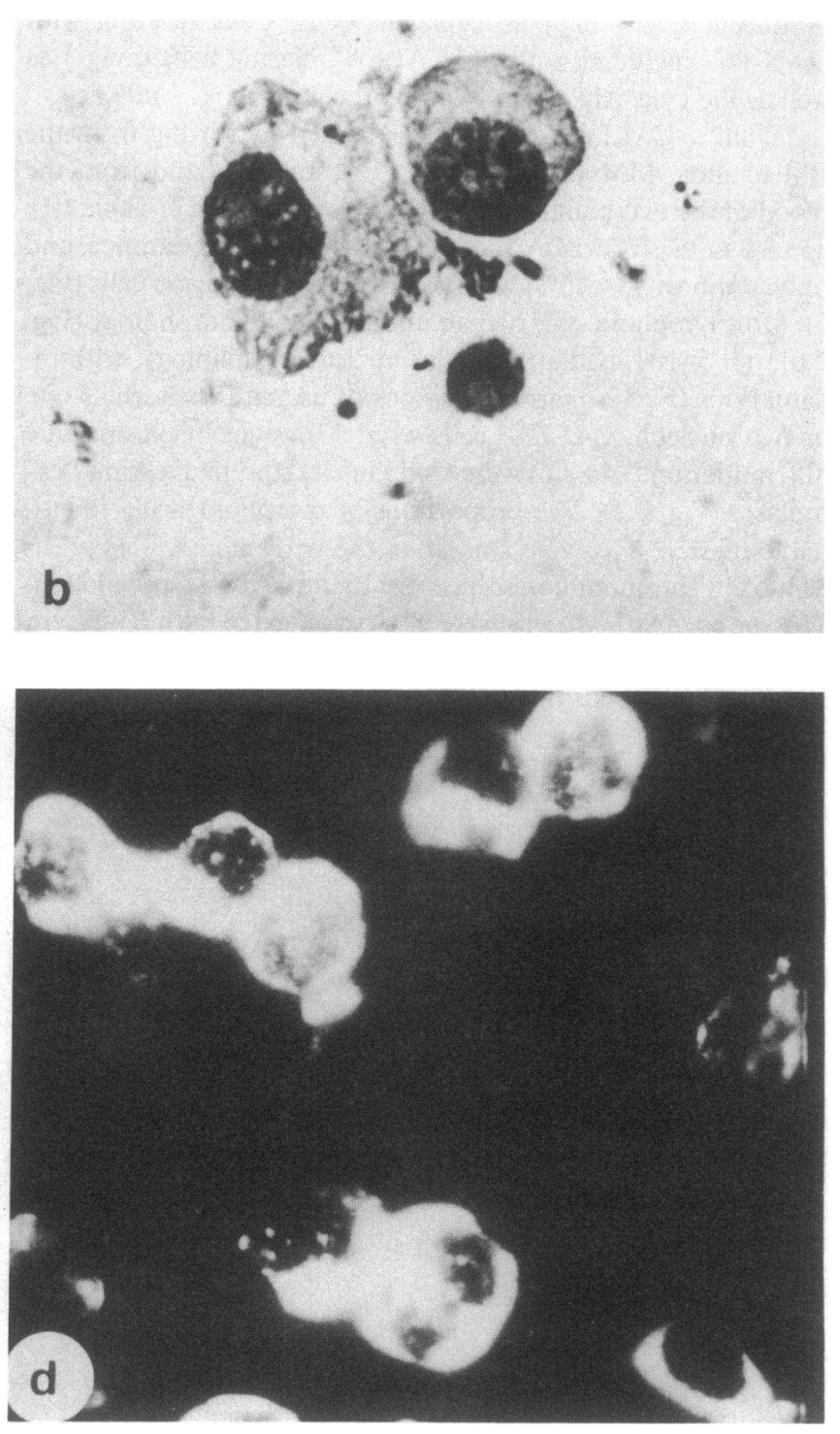

quire plasma cell morphology ( $a$ and $b$ ) and abundantly express monoclonal light $(c)$ and heavy chains $(d)$.

Table IV. TPA-induced Changes in CALLA ${ }^{+}$Cells Purified with FACS and Cultured for $72 \mathrm{~h}$

\begin{tabular}{|c|c|c|c|c|c|c|}
\hline \multirow[b]{3}{*}{ Case No.* } & \multicolumn{3}{|c|}{$\mathrm{CALLA}^{+}$cells (\%) } & \multicolumn{3}{|c|}{ cylg $^{+}$cells $(H / L)(\%) \S$} \\
\hline & \multirow{2}{*}{$\begin{array}{l}\text { Before } \\
\text { culturing }\end{array}$} & \multicolumn{2}{|c|}{ After $72 \mathrm{~h}$} & \multirow{2}{*}{$\begin{array}{l}\text { Before } \\
\text { culturing }\end{array}$} & \multicolumn{2}{|c|}{ After $72 \mathrm{~h}$} \\
\hline & & C & TPAł & & $\mathbf{C}$ & TPA \\
\hline $1(\mathrm{G} / \kappa)$ & 92 & 5 & $<1$ & $12 / 11$ & $10 / 10$ & $43 / 45 \mathrm{G} / \kappa$ \\
\hline $9(G / \lambda)$ & 91 & 9 & $<1$ & $10 / 12$ & $16 / 18$ & $68 / 69 \mathrm{G} / \lambda$ \\
\hline $10(\mathrm{~A} / K)$ & 97 & 7 & $<1$ & $18 / 18$ & $18 / 18$ & $61 / 60 \mathrm{~A} / \mathrm{k}$ \\
\hline $11(\mathrm{G} / \kappa)$ & 94 & 5 & $<1$ & $18 / 17$ & $3 / 2$ & $30 / 50 \mathrm{G} / \mathrm{k}$ \\
\hline $12(G / \lambda)$ & 95 & 8 & $<1$ & $15 / 15$ & $15 / 15$ & $59 / 58 \mathrm{G} / \lambda$ \\
\hline
\end{tabular}

* The features of cases are shown in Table III.

¥ TPA-treated cells undergo morphological changes (see text and Fig. $3)$.

$\S \mathbf{H}$, heavy chain; L, light chain. 


\section{Discussion}

The aim of this study was to investigate whether MM might be considered as a tumor differentiating from precursor cells. We have therefore attempted to identify the features of these precursor cells in the myelomatous BM, and demonstrated that these "early" cells are capable of transforming into plasma cells with monoclonal light and heavy chain expression. These precursor cells are not conventional B lymphocytes; they are $\mathrm{CALLA}^{+}$lymphoidlike cells that fail to express TdT and cytoplasmic or membrane Ig. After TPA induction, the heavy chain in the activated cells is of the post-switch type ( $\gamma$ and $\alpha$ ), and the light chain also faithfully reproduces the isotype displayed by myeloma cells in the individual patients. Thus, our study not only confirms the data of Ruiz-Argüelles et al. (26) about the presence of CALLA ${ }^{+}$cells in some cases of MM but, in addition, extends the observations by showing that many of these CALLA ${ }^{+}$ cells become plasma cells after TPA induction.

While many patients with MM had these CALLA ${ }^{+}$cells in the BM, some of the cases studied had very low proportions of these cells $(0.1-0.4 \%)$, which might have been missed by the previous study (26). The observations of CALLA ${ }^{+}$lymphoid cells and plasma cells have also been facilitated by use of APAAP technique, which gives a strong amplification and a precise morphological definition (23).

The lineage affiliation of $\mathrm{CALLA}^{+}$elements in MM is an intriguing question. Within the normal hematopoietic system, CALLA is expressed by a few mononuclear cells $(24,27)$ that are regarded as immature lymphoid precursors probably committed to the B lymphocyte pathway $(28,29) ;>60 \%$ of the cells contain the nuclear enzyme $\mathrm{TdT}(24,30)$ and are $\mathrm{BA}^{+}(\mathrm{CD} 24$; reference 31$)$ and $\mathrm{B}^{+}(\mathrm{CD} 19$; reference 29$)$, but only some are also $\mathrm{B}^{+}{ }^{+}$(CD20) (19). These $\mathrm{TdT}^{+}, \mathrm{CALLA}^{+}$cells express p140 (CD22) in their cytoplasm (19). In MM, on the other hand, the $\mathrm{CALLA}^{+}$cells are TdT negative and $\mathrm{BA}-1^{-}, \mathrm{B}^{-}$, and $\mathrm{B}^{-}$. These cells also fail to express CD22 antigen in their cytoplasm. Furthermore, separated $\mathrm{CALLA}^{+}$cells remained negative for all these B cell-associated antigens after the cultivation period (72 h) even when they were incubated with TPA. In conclusion, while the $\mathrm{CALLA}^{+} \mathrm{MM}$ cells develop into morphologically identifiable plasma cells, they remain negative for those $B$ cell markers (CD19, CD22, and CD24) that would be expected to appear on both the normal CALLA ${ }^{+}$pre-B cells and on B lym-

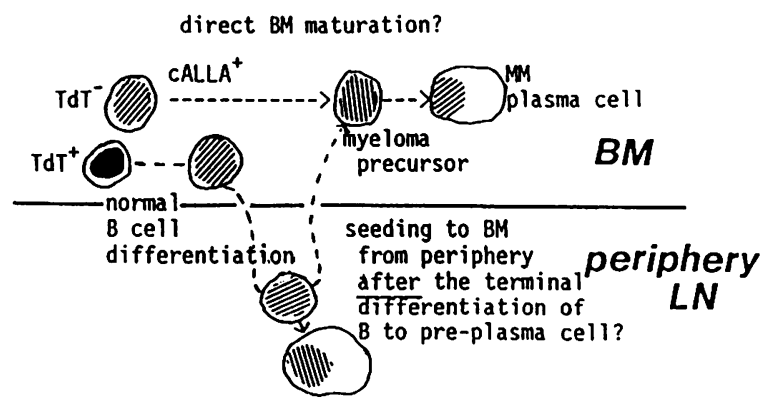

Figure 4. Putative relationships of $\mathrm{CALLA}^{+}$precursors in $\mathrm{MM}$ to other pre-B and B cell populations. The CALLA ${ }^{+}$-positive BM precursors appear to be heterogeneous in terms of TdT expression. It is not known whether the CALLA ${ }^{+} \mathrm{MM}$ precursor cells are close relatives of $\mathrm{CALLA}^{+}, \mathrm{TdT}^{+}$cells, or derive from a previously stimulated $\mathrm{B}$ cell population that has undergone $B$ cell to preplasma cell differentiation in the peripheral lymphoid tissue and returned to the BM. phocytes. These findings strongly indicate that these peculiar variants of $\mathrm{CALLA}^{+}$cells in $\mathrm{MM}$ are different from the majority of CALLA ${ }^{+}$cells seen in the normal BM (Fig. 4). In addition, these cells also lack detectable cyIg and sIg, but, as shown above, cylg can be induced in these CALLA ${ }^{+}$cells by TPA. Further, plasma cell associated features, such as $\mathrm{HAN}-\mathrm{PC}_{1}$ antigen, can also be demonstrated in these cells. On the basis of these results, we regard this subset as a preplasma cell population.

The newly identified CALLA ${ }^{+}$cells are not mature plasma cells, as they have lymphoid morphology and do not express cylg. Furthermore, these cells are $\mathrm{HLA}_{-} \mathrm{DR}^{+}$, while plasma cells are HLA-DR ${ }^{-}$(32). The T10 expression on these cells is weaker than seen on fully developed plasma cells but stronger than on normal resting $B$ cells.

The response of $\mathrm{CALLA}^{+}$cells to TPA in MM is unique amongst CALLA ${ }^{+}$cells of the hemopoietic system. In the normal $\mathrm{BM}, \mathrm{CALLA}^{+}$cells after induction with TPA acquire the B1 antigen but do not transform into plasma cells (33). Nalm-6 and $\mathrm{KM} 3$ lymphoid cell lines $\left(\mathrm{CALLA}^{+}\right)$do not change their morphology when incubated with TPA, but express $B$ cell antigens CD22 (19). Finally, lymphoblasts from patients with pre-B ALL express cy- $\mu$ chains (34-36), but do not acquire Ig of the postswitch isotype ( $\gamma$ or $\alpha$ ) in TPA-induced cultures $(37,38)$.

These data, taken together, indicate that the CALLA ${ }^{+}$cells may represent a unique preplasma cell population in $\mathrm{MM}$ and PCL. As these cells appear to be negative for Ig (even when studied with the sensitive APAAP method), they have been missed by studies using anti-Ig (idiotype) markers. The induction of high intensity monoclonal ( $\kappa$ or $\lambda$ ) Ig by TPA establishes a link between the precursor and its descendants. An unexplained observation is that these precursors lack the TdT enzyme and most established B cell-associated markers (CD19-22, CD24), indicating that when these cells develop into plasma cells they "skip" or bypass mature B cell development. The origin of the preplasma cells remains to be established.

The clinical significance of our findings is as follows. $\mathrm{CALLA}^{+}$cells are observed mostly in the aggressive forms such as MM stages II and III, and PCL, but are low in number during MM stage I and absent in benign forms such as BMG and IP. The single CALLA ${ }^{+}$cell we have seen in BMG was a normal $\mathrm{TdT}^{+}$precursor. Our data, based on a short followup of 3-15 mo, suggest that patients with $>5 \% \mathrm{CALLA}^{+}$cells in the BM may have a more rapid downhill course than those with no identifiable CALLA ${ }^{+}$cells. Furthermore, in the stage II and III of MM, CALLA ${ }^{+}$cells may also appear in the peripheral blood, a further sign of poor prognosis. This observation confirms the findings of Ruiz-Argüelles et al. (26), and also supports the view that blood-borne lymphoidlike cells may contribute to the dissemination of disease. Still, the number of these blood cells is very low. A further study is in progress to investigate the DNA abnormalities, as well as the mitotic and clonogenic activity of these $\mathrm{CALLA}^{+}$preplasma cells.

Sequential BM biopsies in MM patients occasionally reveal a progressive shift from mature plasma cells to an immature plasmablast population that fails to produce detectable Ig (3942). These terminal immunoblastic lymphomas $(43,44)$ and "reticulum cell sarcomas" (45-47) in MM patients may represent an analogous disease-progress to the "blast crisis" seen in chronic myeloid leukemia (48). In fact, Van Den Berghe et al. (49) reported the presence of Philadelphia $\left(\mathrm{Ph}^{\prime}\right)$ chromosome in aggressive forms of plasma cell malignancies, while Karpas et al. (50) obtained a $\mathrm{Ph}^{\prime}$ positive human myeloma cell line. The lack 
of Ig production in some of these cases is probably better explained by the emerging dominance of $\mathrm{Ig}^{-}, \mathrm{CALLA}^{+}$clonogenic cells (which fail to differentiate into plasma cells), rather than by the "loss" of Ig production in mature plasma cells.

\section{Acknowledgments}

This work was supported by Progetto Finalizzato Oncologia, CNR, Roma, grant 84.00402.44 to Dr. Caligaris-Cappio, and 84.00741.44 to Dr. Pizzolo, by Progetto Finalizzato Ingegneria Genetica e Basi Molecolari delle Malattie Ereditarie, Consiglio Nazionale delle Ricerche, Roma, to Dr. Malavasi, and partly by Ministero della Pubblica Istruzione.

\section{References}

1. Galton, D. A. G. 1981. Myelomatosis. In Postgraduate Haematology. A. V. Hoffbrand and S. M. Lewis, editors. W. Heinemann Medical Books Ltd., London. 513-542.

2. Drewinko, B., R. Alexanian, H. Boyer, B. Barlogie, and S. I. Rubinow. 1981. The growth fraction of human myeloma cells. Blood. 57: 333-338.

3. Pileri, A., and R. P. Tarocco. 1974. In vivo kinetic studies in human myeloma. Haematologica. 59:10-24.

4. Lynch, R. G., J. M. Rohrer, B. Odermatt, H. M. Gebel, J. R. Autry, and R. G. Hoover. 1979. Immunoregulation of murine myeloma cell growth and differentiation: a monoclonal model of B cell differentiation. Immunol. Rev. 48:45-80.

5. Warner, T. F. C. S., H. L. Moses, D. S. Fair, and R. G. Krueger. 1977. Circulating tumor cells in murine myeloma. J. Nat. Cancer Inst. 58:983-992.

6. Hamburger, A. W., and S. E. Salmon. 1977. Primary bioassay of human myeloma stem cells. J. Clin. Invest. 60:846-854.

7. Bernard, A., L. Boumsell, J. Dausset, C. Milstein, and S. F. Schlossman. 1984. Leucocyte Typing. Springer-Verlag, Berlin. pp. 1814.

8. Nadler, L. 1985. B cell antibody clusters of the Boston panel. In Leucocyte Typing. E. Reinherz, L. Nadler, J. Hansen, and S. F. Schlossman, editors. Academic Press, London, New York, Toronto. In press.

9. Durie, B. G. M., and S. E. Salmon. 1975. A clinical staging system for multiple myeloma. Cancer. 36:842-854.

10. Chronic Leukemia-Myeloma Task Force, National Cancer Institute. 1973. Proposed guidelines for protocol studies. II. Plasma cell myeloma. Cancer Chemother. Rep. 4:145-158.

11. Gobbi, M., F. Caligaris-Cappio, D. Campana, P. L. Tazzari, L. Bergui, M. Cavo, and S. Tura. 1984. Functional behaviour and immunological phenotype of circulating B lymphocytes in multiple myeloma. Studies with pokeweed mitogen. Clin. Exp. Immunol. 58:625-630.

12. Gobbi, M., F. Caligaris-Cappio, and G. Janossy. 1983. Normal equivalent cells of $B$ cell malignancies: analysis with monoclonal antibodies. Br. J. Haematol. 54:393-403.

13. Minowada, J., G. Janossy, M. F. Greaves, T. Tsubota, B. I. S. Srivastava, S. Morikawa, and E. Tatsumi. 1978. Expression of an antigen associated with acute lymphoblastic leukemia in human leukemia-lymphoma cell lines. J. Nat. Cancer Inst. 60:1269-1277.

14. Ritz, J., J. M. Pesando, J. Notis-McConarty, H. Lazarus, and S. F. Schlossman. 1980. A monoclonal antibody to human acute lymphoblastic leukemia antigen. Nature (Lond.) 283:583-585.

15. Knapp, W., O. Majdic, P. Bettelheim, and K. Liszka. 1982. VilAl, a monoclonal antibody reactive with common acute lymphatic leukemia cells. Leuk. Res. 6:137-147.

16. Nadler, L. M., K. C. Anderson, G. Marti, M. Bates, E. Park, J. F. Daley, and S. F. Schlossman. 1983. B4, a human B lymphocyteassociated antigen expressed by normal, mitogen-activated and malignant B lymphocytes. J. Immunol. 131:244-250.

17. Stashenko, P., L. M. Nadler, R. Hardy, and S. F. Schlossman. 1980. Characterization of a human B-lymphocyte-specific antigen. $J$. Immunol. 125:1678-1685.
18. Abramson, C. S., J. H. Kersey, and T. W. Le Bien. 1981. A monoclonal antibody (BA-1) reactive with cells of human B lymphocyte lineage. J. Immunol. 126:83-88.

19. Campana, D., G. Janossy, M. Bofill, L. K. Trejdosiewicz, D. Ma, A. V. Hoffbrand, D. Y. Mason, A. M. Lebacq, and H. Forster. 1985. Human B cell development. I. Phenotypic difference of B lymphocytes in the bone marrow and peripheral lymphoid tissue. J. Immunol. 134: 1524-1530.

20. Kersey, J. H., T. W. Le Bien, C. S. Abramson, R. Newman, R. Sutherland, and M. F. Greaves. 1981. p24: a human leukemia-associated and lymphohemopoietic progenitor cell surface structure identified with monoclonal antibody. J. Exp. Med. 153:726-731.

21. Malavasi, F., F. Caligaris-Cappio, C. Milanese, P. Dellabona, P. Richiardi, and A. O. Carbonara. 1984. Characterization of a murine monoclonal antibody specific for human early lymphohemopoietic cells. Hum. Immunol. 9:9-20.

22. Mertens, R., M. F. Dehou, H. Vanderbruggen, I. Van Riet, and B. Van Camp. 1985. A monoclonal antibody (HAN-PC1) reacting with a maturation antigen on plasma cells. H. D. Peeters, editor. In Protioles Biological Fluids. Proceedings 32nd Colloquium. Pergamon Press, Oxford. 32:891-895.

23. Moir, D. G., A. K. Ghosh, Z. Abdulaziz, P. M. Knight, and D. Y. Mason. 1983. Immunoenzymatic staining of haematological samples with monoclonal antibodies. Br. J. Haematol. 55:395-410.

24. Janossy, G., F. J. Bollum, K. F. Bradstock, A. McMichael, N. Rapson, and M. F. Greaves. 1979. Terminal transferase-positive human bone marrow cells exhibit the antigenic phenotype of common acute lymphoblastic leukemia. J. Immunol. 123:1525-1529.

25. Caligaris-Cappio, F., G. Janossy, D. Campana, M. Chilosi, L. Bergui, R. Foa, D. Delia, M. C. Giubellino, P. Preda, and M. Gobbi. 1984. Lineage relationship of chronic lymphocytic leukemia and hairy cell leukemia: studies with TPA. Leuk. Res. 8:567-578.

26. Ruiz-Argüelles, G. J., J. A. Katzmann, P. R. Greipp, N. J. Gouchoroff, J. P. Garton, and R. A. Kyle. 1984. Multiple myeloma: circulating lymphocytes that express plasma cell antigens. Blood. 64:352-356.

27. Greaves, M. F., G. Hariri, R. A. Newman, D. R. Sutherland, M. A. Ritter, and J. Ritz. 1983. Selective expression of the common acute lymphoblastic leukemia (gp100) antigen on immature lymphoid cells and their malignant counterparts. Blood. 61:628-639.

28. Korsmeyer, S. J., A. Arnold, A. Bakhshi, J. W. Ravetch, U. Siebenlist, P. A. Hieter, S. O. Sharrow, T. W. LeBien, J. H. Kersey, D. G. Poplak, P. Leder, and T. A. Waldmann. 1983. Immunoglobulin gene rearrangement and cell surface antigen expression in acute lymphocytic leukemias of T cell and B cell precursor origin. J. Clin. Invest. 71:301313.

29. Nadler, L. M., S. J. Korsmeyer, K. C. Anderson, A. W. Boyd, B. Slaughenhoupt, E. Park, J. Jensen, F. Coral, R. J. Meyer, S. E. Sallan, J. Ritz, and S. F. Schlossman. 1984. B cell origin of non-T cell acute lymphoblastic leukemia: a model for discrete stages of neoplastic and normal pre-B cell differentiation. J. Clin. Invest. 74:332-340.

30. Hokland, P., L. M. Nadler, J. D. Griffin, S. F. Schlossman, and J. Ritz. 1984. Purification of common acute lymphoblastic leukemia antigen positive cells from normal human bone marrow. Blood. 64:662666.

31. Bodger, M. B., G. Janossy, F. J. Bollum, G. D. Burford, and A. V. Hoffbrand. 1984. The ontogeny of terminal deoxynucleotidyl transferase positive cells in the human fetus. Blood. 61:1125-1131.

32. Halper, J., S. M. Fu, C. Y. Wang, R. Winchester, and H. G. Kunkel. 1978. Patterns of expression of human "Ia-like" antigens during the terminal stages of B cell development. J. Immunol. 120:1480-1484.

33. Hokland, P., J. Ritz, S. F. Schlossman, and L. M. Nadler. 1984. Direct evidence for an orderly expression of B-cell differentiation antigens defined by monoclonal antibodies during phorbol ester induced differentiation of normal human fetal lymphoid progenitor cells. 1st Int. Meet. Monoclonal Antibodies Haemopathology. (Abstr.)

34. Vogler, L. B., W. M. Crist, D. E. Bockman, E. R. Pearl, A. R. Lawton, and M. D. Cooper. 1978. Pre-B cell leukemia: a new phenotype of childhood lymphoblastic leukemia. N. Engl. J. Med. 298:872-878. 
35. Brouet, J. C., J. L. Preud'homme, C. Penit, F. Valensi, P. Rouget, and M. Seligmann. 1979. Acute lymphoblastic leukemia with pre-B cell characteristics. Blood. 54:269-273.

36. Greaves, M. F., W. Verbi, L. B. Vogler, M. D. Cooper, R. Ellis, K. Ganeshaguru, V. Hoffbrand, G. Janossy, and F. J. Bollum. 1979. Antigenic and enzymatic phenotypes of the pre-B subclass of acute lymphoblastic leukemia. Leuk. Res. 3:353-362.

37. Cossman, J., L. M. Neckers, A. Arnold, and S. J. Korsmeyer. 1982. Induction of differentiation in a case of common acute lymphoblastic leukemia. N. Engl. J. Med. 307:1251-1254.

38. Nadler, L. M., J. Ritz, M. P. Bates, E. K. Park, K. C. Anderson, S. E. Sallan, and S. F. Schlossman. 1982. Induction of human B cell antigens in non-T cell acute lymphoblastic leukemia. J. Clin. Invest. 70: 433-442.

39. Taylor, C. R., R. Russell, and S. Chandor. 1978. An immunohistologic study of multiple myeloma and related conditions, using an immunoperoxidase method. Am. J. Clin. Pathol. 70:612-622.

40. Sasrabudhe, D. M., and J. C. Parker. 1981. Decreasing M spike with increasing tumor burden in multiple myeloma. Arch. Intern. Med. 141:1152-1153.

41. Suchman, A. L., M. Coleman, J. A. Mouradian, D. J. Wolf, and S. Salltan. 1981. Aggressive plasma cell myeloma. A terminal phase. Arch. Intern. Med. 141:1315-1320.

42. Garewal, H., and B. G. M. Durie. 1982. Aggressive phase of multiple myeloma: acute pneumonia-like presentation with rapidly pro- gressive pulmonary infiltrates and fever. J. Am. Med. Assoc. 248:18751876.

43. Hobbs, J. R. 1975. Monitoring myelomatosis. Arch. Intern. Med. 135:125-130.

44. Falini, B., I. De Solas, A. M. Levine, J. W. Parker, R. J. Lukes, and C. R. Taylor. 1982. Emergence of B-immunoblastic sarcoma in patients with multiple myeloma: a clinicopathologic study of 10 cases. Blood. 59:923-933.

45. Durrant, J. R., W. E. Barry, and N. Learner. 1966. The changing face of myeloma. Lancet. I:119-121.

46. Okano, H., H. A. Azar, and E. F. Osserman. 1966. Plasmacytic reticulum cell sarcoma: case report with electron microscopic studies. Am. J. Clin. Pathol. 46:546-552.

47. Holt, J. M., and A. H. T. Robb-Smith. 1973. Multiple myeloma: development of plasma cell sarcoma during apparently successful chemotherapy. J. Clin. Pathol. 26:649-659.

48. Janossy, G., M. Roberts, and M. F. Greaves. 1976. Target cell in chronic myeloid leukaemia and its relationship to acute lymphoid leukaemia. Lancet. II:1058-1061.

49. Van Den Berghe, H., A. Louwagle, A. Broeckaert-Van Orshoven, G. David, R. Verwilghem, J. L. Michaux, and G. Sokal. 1979. Philadelphia chromosome in human multiple myeloma. J. Nat. Cancer Inst. 63:11-16.

50. Karpas, A., P. Fischer, and D. Swirsky. 1982. Human myeloma cell line carrying a Philadelphia chromosome. Science (Wash. DC). 216: 997-999. 